\title{
Melihat Freire Bekerja di Kampus Kita; Telaah Reflektif-Kritis Buku Siti Murtiningsih "Pendidikan; Alat Perlawanan"
}

"Sebenarnya, saya tidak suka suasana pembelajaran di ruang kelas apalagi dengan beberapa mata kuliah tapi saya memaksakan suka saja karena saya mau mendapatkan nilai (skor) yang bagus", kiriman narasi yang terdengar dari salah seorang perempuan yang duduk di bangku sebelah di sebuah kantin kampus. Sebuah percakapan yang terlintas di benak mengurai beberapa tanya, mungkinkah banyak peserta didik di perguruan tinggi merasakan hal demikian? Alhasil, beberapa pendiskusian dengan peserta didik yang berkecimpung di pendidikan tinggi melontarkan pandangan yang hampir sama. "saya mau mendapatkan pengetahuan lebih dalam ruang perkuliahan", "saya mau belajar sesuai minat saya", "saya mau melatih kemampuan diri saya di kampus", "saya mau....", "saya mau...". Sekilas rangkuman keresahan-keresahan yang hadir hari ini, lantas kenapa tidak memberanikan diri untuk mengutarakan permasalahan itu kepada para tenaga pendidik? "saya takut, nanti nilai saya dipengaruhi hanya karena saya bertanya seperti itu", "saya sudah menanyakan hal demikian namun jawabannya bahwa ini memang sistem jadi silahkan ikuti saja" dan beberapa jawaban-jawaban lainnya yang hampir sama.

Ideologi pendidikan tinggi dewasa ini memang lebih mengarah kepada 'pendisiplinan' yang selain didukung oleh kebijakan tentang pendidikan itu sendiri juga didukung oleh kondisi ruang-ruang kelas yang tidak dialogis atau antara tenaga pendidik (subjek) dan peserta didik (objek), sebuah terma pendidikan yang memposisikan para peserta didik sebagai objek yang harus diisi dengan kapital ilmu pengetahuan yang dimiliki oleh tenaga pendidik selaku subjek. Tidak adanya proses uji coba melalui proses dialog atas ilmu pengetahuan yang disalurkan oleh tenaga pendidik dalam ruang kelas atau perkuliahan akan menghasilkan peserta didik yang berada dalam ruang ketidaksadaran. Fenomena tersebut akan melahirkan para peserta didik yang kaku dan tidak sadar diri, hal demikian tentunya bergeser daripada konsep pendidikan sebagai pembentukan pribadi peserta didik atau manusia.

Pendidikan pada umumnya adalah sebuah usaha sadar manusia dalam menyelaraskan kepribadiannya dengan keyakinan dan nilai-nilai yang beredar dan berlaku dalam masyarakat berikut kebudayaannya. Dalam ruang perkuliahan misalnya, proses pembangunan karakter peserta didik akan tumbuh jika metode bercerita dalam penyampaian bahan ajar oleh para tenaga pendidik diubah menjadi proses dialogis yang meniscayakan keterbukaan dan keterlibatan secara penuh antara tenaga pendidik (dosen) dan peserta didik (mahasiswa) dalam mendudukkan dan membedah bahan ajar sebagai objek.

Metode pendidikan berpola dialog dikemukakan oleh Paulo Freire, seorang pemikir pendidikan yang berdiri di atas jalur kritis-progresif ${ }^{1}$. Pendekatan kritis-progresif ala Freire

\footnotetext{
${ }^{1}$ Pendidikan berpola dialog yang berjalur kritis-progresif digambarkan oleh Paulo Freire dalam dua bukunya yang telah diterjemahkan ke dalam Bahasa Indonesia, Pendidikan Kaum Tertindas dan Pendidikan sebagai Praktek Pembebasan, buku yang berisi pemikiran radikal dalam dunia pendidikan meskipun ia sendiri tidak pernah menganggap karyanya seperti itu.
} 
lebih menekankan pada penumbuhan sikap kritis dan kreatif peserta didik. Peserta didik tidak dipahami sebagai objek tersendiri yang harus digarap dan diisi namun harus diterima sebagai subjek yang dilengkapi kemampuan untuk mengubah realitas yang dihadapinya ke arah yang lebih baik ${ }^{2}$. Pendidikan yang mengobjektifikasi peserta didik sama dengan memperbodohnya sehingga tidak terjadi perkembangan kesadaran (Sutrisno, 1995: 22).

Fenomena peserta didik atau mahasiswa yang dijadikan objek dalam perguruan tinggi, tepatnya dalam ruang perkuliahan merupakan kisah monumental yang sampai hari ini masih dilakonkan dengan begitu apik oleh tenaga pendidik (dosen). Tentunya kisah monumental itu harus diakhirikarena yang akan dilahirkan dengan model pendidikan seperti ini adalah pribadi yang kehilangan jati diri bukan pribadi yang sadar akan orientasinya. Orientasi yang dimaksud di sini adalah pribadi yang berkembang dengan bahasa pikirannya, sebagai contoh seseorang yang tidak hanya sanggup menjalani kehidupannya, melainkan mengerti dan mampu mengubah realitas kehidupan yang tidak ramah pada dirinya dan orang lain.

Pendidikan sebagai arena bagi manusia untuk mengembangkan karakternya secara sadar dengan berkaca pada kodratnya yang tidak hanya berada-dalam-dunia namun beradabersama-dengan-dunia dalam artian sederhananya bahwa pendidikan memiliki peran penting terhadap manusia yang bernaung di bawahnya, peserta didik dan tenaga pendidik, untuk menumbuhkan kesadaran bahwa mereka memiliki tanggung jawab moral yakni menciptakan dunia dalam realitas yang memberikan ruang kepada setiap manusia untuk memperoleh haknya tanpa adanya pola diskriminasi dan saling menindas. Mereka yang pernah mengenyam dunia pendidikan menjadi keharusannya untuk membangun tatanan dunia yang adil terhadap masyarakat umum dan berdiri tegak menghadapi segala permasalahan yang menjadi benalu dalam kehidupan masyarakat.

Oleh karena itu, model pendidikan khususnya pendidikan tinggidiharuskan menjadi ruang penyadaran manusia agar di kemudian hari para individu yang pernah merasakan bangku pendidikan mampu menerjemahkan konstruk zaman dan menyelami realitas sosial yang berprikemanusiaan maka perlu kiranya pembelajaran dalam ruang perkuliahan tidak monoton pada perkara duniawi yang bersampul untung-rugi melainkan menghadirkan pembelajaran yang tidak terlepas daripada kenyataan sosial sehingga melahirkan manusia yang tidak anti kehidupan sosial.

Citra pendidikan khususnya pendidikan tinggi di perguruan tinggi yang menjadikan pendidikan sebagai kendaraan untuk kesuksesan masa depan menjadi momok yang menggiurkan. Pendidikan sebagai arena peretas kemiskinan di masa yang akan datang dan ditempuh hanya untuk mencari pekerjaan. Ihwal seperti ini kiranya didaur-ulang karena pada hakikatnya yang akan tercipta bukanlah para generasi muda yang memperhatikan keberlangsungan negeri ini melainkan para calon pekerja yang memprioritaskan pekerjaan dan kekayaan meskipun hal demikian tidak bisa dipungkiri untuk memenuhi kebutuhan

\footnotetext{
${ }^{1}$ Tesis Siti Murtiningsih yang disunting Resist Book ke dalam bentuk buku, Pendidikan; Alat Perlawanan, hal.7
} 
namun perlu digarisbawahi bahwa manusia bukan hanya hidup di dalam dunia ini melainkan hidup bersama dunia.

\section{Konsep Pendidikan Paulo Freire dan Relevansinya di Kampus Peradaban}

Paulo Freire, seorang pemikir yang terkenal dengan teori pendidikan radikalnya sangat berkontribusi pada sistem pendidikan yang ada di negara dunia ketiga. Melalui elaborasi yang begitu apik dari Siti Murtiningsih dalam tesis pasca sarjananya di UGM yang kemudian disunting dan dibukukan oleh Resist Book serta diberi judul "Pendidikan Alat Perlawanan; Teori Pendidikan Radikal Paulo Freire". Buku yang memiliki 130 halaman ini cukup menyajikan polemik pendidikan secara umum di Indonesia dan kemudian coba diejawantahkan dengan kondisi pendidikan tinggi di kampus khususnya di UIN Alauddin Makassar melalui tulisan ini dengan menggunakan pendekatan fenomenologi.

\section{- Temuan 1}

Tatkala rakyat dalam keadaan takut, para penguasa memperkuat kedudukannya dengan mengembangbiakkan mitos-mitos yang menumpulkan kesadaran kritis kaum tertindas. Mitos-mitos itu seperti misalnya; bahwa menumpuk-numpuk kekayaan adalah hak yang sepatutnya dan tidak perlu disangkal lagi; bahwa seseorang menjadi kaya karena ia berusaha keras dan berani mengambil resiko; bahwa apabila seseorang miskin dan tidak dapat hidup layak itu karena ia tidak mampu, malas, serta tidak tahu berterima kasih; bahwa pemberontakan merupakan dosa besar terhadap Tuhan; juga bahwa cinta kasih serta kemurahan hati kaum elit disebabkan karena mereka rela menolong.

Pada gilirannya mitos-mitos ini menyebabkan rakyat yang tertindas menjadi takut akan kebebasan. Mereka melembagakan gambaran diri sebagai kaum tertindas yang dalam dirinya membentuk sikap yang turut memperkuat siasat-siasat licik kaum penindas tersebut. Pandangan-pandangan bahwa mereka tidak tahu apaapa, sama sekali tidak berguna, malas dan lemah, tak mau belajar, adalah suara-suara yang paling akrab mereka dengar. Akibatnya mereka buta akan realitas sosial yang sangat represif. Mereka meyakini bahwa kondisi mereka seperti itu adalah yang semestinya terjadi dan karenanya pantas diterima. Dengan begitu kesadaran mereka lantas terdistorsi. (hal 22)

Pada paragraf pertama menggambarkan sebuah fenomena yang menjadi sebab dari sebuah permasalahan. Dalam wilayah kampus, hal demikian akan nampak pada sisi kebijakan dan model ruang perkuliahan. Kebijakan yang dikeluarkan oleh pendidik (pimpinan kampus) kerapkali menawarkan sebuah ketakutan kepada peserta didik (mahasiswa) yang tentunya mempengaruhi kesadaran. Contoh mitos yang pernah beredar yakni kebijakan masa studi 4 tahun yang jika lebih dari pada itu maka mahasiswa akan dikenakan tarif kuliah 2x lipat, secara spontan kebanyakan mahasiswa memilih bergegas dan memacu penyelesaian tanpa memikirkan kebenaran dari kebijakan tersebut sehingga kemampuan intelektual digantikan dengan keinginan untuk menyelesaikan studi secepatnya serta ditambah lagi dengan penekanan di ruang perkuliahan oleh para pendidik. Mitos seperti ini dinilai sebagai bentuk penumpulan dan pendangkalan kesadaran mahasiswa.

Para paragraf kedua menggambarkan ihwal yang menjadi akibat dari pada sebab. Mitos-mitos tersebut mengarahkan para mahasiswa menjauh dari hal yang terbilang intim yakni kesadaran dan realitas sosial. Mahasiswa sebagai ujung tombak perubahan dan pengontrol lajur sosial menjelma menjadi individu-individu yang anti sosial. 
Konstruksi pendidikan seperti ini hanya akan melahirkan The Culture of Silence (Kebudayaan Bisu), mahasiswa dianggap sebagai objek sedang para pendidik adalah subjek sehingga mahasiswa akan tampil bukan karena dirinya.

\section{- Temuan 2}

Corak pemikiran filosofis Freire; Personalisme (emmanuel de mounier), Eksistensialisme (Sartre, Heiddegger), Fenomenologi (Husserl, Maurice Marleau-Ponty), Marxisme dan Kristianisme. (hal 25-34)

Personalisme sebagai sebuah paham percaya kepada Tuhan. Kepercayaan akan kehadiran Sang Pencipta harus dihadapi dengan personalitas sempurna melalui perjuangan yang berdasar pada kesadaran. Eksistensialisme lebih kepada pemberontakan kepada tendensi untuk mereduksi manusia merosot menjadi mesin. Fenomenologi sebagai suatu gerakan filsafat yang melihat sebuah fenomena sebagai kenyataan yang hadir berbasiskan kesadaran. Marxisme sebagai bentuk pendekatan pada sistem kerja yang menolak kehadiran kapitalisme karena dinilai sebagai penghancur kesadaran manusia. Kristianisme sebagai sebuah studi di mana agama dijadikan sebagai alat pembebas dari kekuatan yang menindas berdasarkan ihwal yang tertera dalam kitab-kitab agama yang menghendaki nilai keadilan dan kemanusiaan.

Dari kelima corak landasan teori Freire tersebut maka dapat disimpulkan bahwa semuanya memiliki orientasi untuk menyadarkan manusia. Bagi kampus yang bernuansa agama yang mencolok tentu sebuah keniscayaan untuk menjadikan ajaran dari agama tersebut sebagai salah satu dasar filosofis pengelolaan sistem pendidikannya, misalnya Islam yang memiliki pedoman berlandaskan Al-Quran dan Hadis yang mana keduanya tidak mengindahkan perihal penindasan terhadap kemanusiaan, artinya dalam hal ini individu diarahkan untuk mengolah potensinya secara sadar tanpa unsur memaksakan agar ia mampu memahami diri dan lingkungannya sehingga mampu menjadi pribadi yang cinta akan kemanusiaan. Ajaran Islam tidak hanya dibenturkan pada wilayah penghambaan dalam segi ritualitas melainkan harus diangkat ke permukaan bersama dengan kenyataan dunia.

\section{- Temuan 3}

Tiga tahap refleksi manusia dari kesadaran magis menuju kesadaran kritis.

1. Tahap semi-intransitif, pada tahap ini pemahaman hanya terbentur pada 'doxa'. Manusia menerima segala sesuatunya dengan dalih 'takdir' atau 'kehendak Tuhan'. Pemikiran magis sekaligus fatalistik ini merupakan khas bagi kesadaran tertindas dalam bentuknya yang paling ekstrim.

2. Tahap naif-transitif, mulai mengenali persoalan-persoalan yang muncul di realitas namun masih terisi oleh pendapat-pendapat dan sikap naif. Contoh sikap naif itu adalah penyerderhanaan masalah, mengindentifikasi diri sebagai elit, kecenderungan kembali ke masa lalu, keengganan meneliti sendiri, cenderung menerima penjelasan yang siap pakai, sikap emosional yang masih kuat, tidak jernih dalam berargumentasi, serta lebih gemar melakukan debat dan polemik ketimbang dialog.

3. Tahap transitif-kritis, yakni kesadaran mempercayai bahwa masalah dalam realitas harus dipecahkan. Manusia pada tahap ini dapat tumbuh ketika pemikirannya bergerak keluar ke alam lain dan mulai berdialog dengan orang lain, dengan dunia bahkan dengan tuhannya. Ciri khas dari pada tahap ini adalah adanya penangkapan situasi persoalan dengan sikap yang menyeluruh, matang dan lebih kritis. (Hal. 48) 
Seperti yang diketahui secara bersama bahwa kesadaran manusia memiliki tiga tingkat yakni kesadaran magis, naif dan kritis. Dari ketiga tingkat kesadaran tersebut seharusnya memiliki hubungan satu sama lain dan tidak hanya stagnan di satu tingkat kesadaran yang mendominasi sehingga menuntut lingkungan untuk mendukung fase perkembangan kesadaran tersebut dalam hal ini kampus sebagai arena pengolahan diri peserta didik untuk mencapai tingkat kesadaran tertingi yakni kesadaran kritis. Melirik secara kritis fenomena tingkat kesadaran yang mendominasi khususnya di kampus peradaban dewasa ini yakni kesadaran semi-intransitif (magis) dan naif-transitif.

Kesadaran magis yang dicirikan sebagai bentuk kesadaran yang senantiasa menyandarkan segala peristiwa yang ada pada punggung 'takdir', kesadaran seperti ini berkembang biak dengan model pengajaran yang monoton ke satu arah yakni peserta didik sebagai objek yang terus didominasi oleh pendidik. Hal demikian tidak seharusnya terjadi dalam arena pendidikan karena kita ketahui bersama bahwa manusia memiliki corak pemikiran yang dinamis sekaligus yang membedakannya dengan binatang, sehingga diperlukan model pengajaran yang transformatif bukan indoktrinasi. Manusia adalah makhluk yang berpikir yang tidak seharusnya menyadarkan segalanya kepada dimensi takdir tanpa sebuah ikhtiar.

Selanjutnya kesadaran naif-transitif, tahap kesadaran ini dalam arena kampus yakni peserta didik telah mampu melihat dan mengenali persoalan-persoalan yang timpang di sekitarnya namun masih dalam proses pengenalan dan belum sampai ke dalam inti permasalahan tersebut. Kesadaran seperti ini dapat dilihat secara jelas pada tubuh beberapa aktivis kampus yang condong melihat sebuah permasalahan hanya dari segi dampak yang dihasilkan masalah tersebut tanpa bergerak untuk mendalami akar sebuah masalah sehingga yang terjadi adalah penyedearhanaan masalah tanpa proses analisis, argumentasi lemah hingga kebanyakan dari mereka memiliki sikap emosional yang tinggi. Yang terjadi bukanlah penyelesaian masalah melainkan permasalahan menjadi mengambang.

Fenomena ini pun kerap didukung oleh dua tipikal aktivis kampus yang sama-sama terjebak dalam belenggu kesadaran naif yakni tipikal yang kecanduan nuansa teoritis yang kerap melupakan wilayah praksis (tindakan) dan tipikal yang kecanduan praksis namun krisis basis teoritis. Keduanya kerap terlibat perdebatan sengit berpola saling sindir-menyindir hingga tak ayal gesekan pemecah terjadi dan permasalahan dalam realitas terabaikan.

Kedua tipikal individu ini harus disulam dengan pertemuan yang dialogis, mendudukkan permasalahan di atas meja kritisisme. Namun yang terjadi dewasa ini di kampus peradaban, kedua tipikal mahasiswa itu nampaknya agak susah dipertemukan dikarenakan saling mempertahankan egosentris. Efek domino daripada kesadaran naif yang terus tereproduksi di tubuh para aktivis kampus yakni terciptanya konflik-konflik berskala kecil atau horizontal sehingga permasalahan atau kebijakan dalam kampus yang menunggu disoroti secara kolektif menjadi terbengkalai dan masuk dalam kategori pembiaran.

Kesadaran naif-transitif juga mampu menciptakan pribadi yang terbilang melakukan tindakan pengebirian konstruksi teori sehingga tindakan yang dilakukan lebih kepada sifat sporadis dan tak berjenjang. Oleh karenanya transformasi kesadaran kolektif dalam hal ini kesadaran 
kritis menjadi sebuah keharusan bagi para aktivis kampus agar dalam melihat kebijakan kampus dan realitas sosial secara lebih menyeluruh, lebih kritis dan dengan argumentasi yang matang.

\section{- Temuan4}

Kesadaran kritis merupakan intensionalitas yang pada dasarnya berarti tegangan dan keterarahan kesadaran pada realitas. Istilah ini untuk menjelaskan bahwa kesadaran manusia adalah proses tegangan antara diri subjek dengan realitas di sekitarnya. (Hal.51)

Tujuan utama manusia adalah humanisasi melalui proses pembebasan. Manusia tidak sama dengan binatang, proses untuk menjadi manusia secara penuh hanya mungkin apabila manusia berintegrasi dengan dunia, manusia tak hanya dibekali dengan kemampuan menyesuaikan diri dengan dunia, lebih dari itu, ia juga memiliki kemampuan untuk memilih dan mengubah kenyataan. Dalam kedudukannya sebagai subjek, manusia senantiasa menghadapi pelbagai ancaman dan tekanan, namun ia tetap mampu terus menapaki dan menciptakan sejarah berkat refleksi kritisnya (Freire, 1970: 55). (Hal. 55)

Pada bagian ini, 'tegangan dan keterarahan kesadaran pada realitas' nampak sangat susah untuk tercipta pada ruang pemikiran yang gersang. Hal demikian harus didukung oleh konstruksi tatanan yang segar dan arena yang terbuka sehingga intensionalitas tumbuh subur namun dalam kondisi kampus yang mengatasnamakan 'humanisasi' namun dalam pengelolaannya tidak berorientasi pada proses pembebasan individu sehingga yang akan terjadi hanya terbentur pada wilayah manusia yang mampu beradaptasi tanpa berintegrasi. Manusia kampus harus dibebaskan untuk memilih perkara agar menemukan dirinya serta tidak hanya kemampuan menyesuaikan diri yang dimiliki melainkan kemampuan untuk mengubah kenyataan.

\section{- Temuan 5}

Konsientisasi, menurut Freire, adalah proses di mana manusia mendapatkan kesadaran yang terus semakin mendalam tentang realitas kultural yang melingkupi hidupnya dan akan kemampuannya untuk mengubah realitas itu. (Hal. 63)

Dalam proses mendapatkan kesadaran yang sifatnya dinamis harus dibarengi dengan model pembelajaran yang dialogis namun bukan hanya sekedar dialogis yang hanya merefleksi hubungan manusia dengan dunia tetapi juga titik awal keberadaan manusia di dalam dan bersama dunia. Di dalam kampus, para mahasiswa memiliki kecenderungan tidak berhadapan dan dihadapkan dengan dunia sehingga yang terjadi adalah mahasiswa hanya bisa menginderai permasalahan dalam realitas tanpa mampu mengubahnya karena pada dasarnya mahasiswa tidak hanya bereaksi secara refleks melainkan memilih, menguji, mengkaji dan menguji kembali lalu menciptakan tindakan yang baru lagi. Permasalahan yang terkait matinya kesadaran kritis mahasiswa di dalam kampus tidak lain dan tidak bukan, itu disebabkan oleh kebijakan model pendidikan dan pengajaran yang monoton satu arah.

\section{- Temuan 6}

Sistem pendidikan gaya bank merupakan pendidikan menjadi semacam aktivitas menabung di mana peserta didik duduk sebagai tabungan dan pendidik sebagai penabung. Pendidik memberikan pengajaran seperti mengisi tabungan yang kemudian diterima, dihafal, dan diulangi dengan patuh oleh peserta didik. (Hal. 73) 
Target dari sistem pendidikan gaya bank ini adalah mempertahankan kondisi penjinakan, dominasi pendidik, dan penaklukkan serta membuat peserta didik mudah dikendalikan. (Hal. 80)

Pembiusan kesadaran peserta didik melalui mitos; bahwa semua peserta didik tidak boleh berbeda pendapat dengan pendidik; bahwa pemberontakan terhadap pendidik adalah dosa melawan Tuhan; bahwa pendidik adalah rajin sedangkan peserta didik adalah pemalas; bahwa hak milik merupakan sarana mutlak untuk perkembangan kemanusiaan dan hak ini dapat diperoleh peserta didik dari pendidik karena ia adalah pemilik ilmu sedangkan peserta didik tidak punya apapun. (Hal. 81)

Tidak terjadinya proses konsientisasi yang berbasis dialogis dalam ruang perkuliahan menjadikan sistem pendidikan kita bergaya bank. Mahasiswa dalam hal ini hanya menjadi objek atau tabungan kaku dari para pendidik sehingga output dari model pendidikan ini adalah melahirkan manusia yang melupakan hakikat dirinya hingga akhirnya tatanan dunia manusiawi yang adil menjadi kisah ilusi semata. Mahasiswa sebagai objek dalam ruang perkuliahan akan terus melanggengkan klise dominasi yang menghasilkan kekerasan simbolik, sebuah jenis kekerasan yang bisa dikatakan sebagai kekerasan terparah dalam diri manusia karena melakukan pembiusan bahkan pembunuhan kesadaran manusia. Kekerasan ini bertumbuh kembang melalui proses dominasi struktur kelas sosial, singkatnya kelas atas (pendidik) dan kelas bawah (mahasiswa).

\section{- $\quad$ Temuan 7}

Pendidikan merupakan pembentukan manusia-manusia baru yang akan menciptakan dunia baru. (Hal. 98)

Sementara, makna kebebasan - kesadaran akan makna dan nilai kebebasan - hanya dapat dibina melalui pendidikan. Hal itu karena kekuatan tindakan bebas bergantung pada kekuatan berpikir. Berpikir merupakan satu-satunya sumber kebebasan. Makna kebebasan mendasari manusia agar menjadi dirinya sendiri dan membedakannya dari binatang. Tegaknya asas berpikir dan kebebasan hingga tumbuh kesadaran akan diri dan lingkungan adalah tujuan sejati dari pendidikan. (Hal. 101)

Freire mendesak perombakan orientasi praktik belajar-mengajar yang telah lama mendominasi, yaitu merombak pola dogmatis ke arah pola dialogis-emansipatoris (Freire, 1979: 45). Pola dogmatis, dengan aliran pengetahuan searah (one way communication), dari atas (pendidik) ke bawah (peserta didik), sudah tidak mampu lagi mengantisipasi perkembangan ketimpangan kekuasaan dalam masyarakat kini. Paradigma yang mengandalkan hafalan ini berwatak pasif, tidak menyulut keberaniaan, penalaran, dan kreativitas. Padahal nalar dan kreativitas inilah yang dibutuhkan rakyat yang tertindas untuk melawan. (Hal. 106)

Model pendidikan khususnya di kampus kita dan umumnya di Indonesia harus lebih memberikan kebebasan berpikir kepada manusia di dalamnya agar dunia yang timpang mampu diperbaiki oleh mereka dengan pola konsientisasinya, hal demikian hanya bisa tercapai jika para pendidik mencoba menepis corak dominasinya yang cenderung menguasai para peserta didik. Mereka, para pendidik, harus menjadikan peserta didik sebagai parnernya dalam melihat dunia yang luas dengan alas pemikiran yang kritis. Keduanya harus saling terbuka dan rendah diri sehingga kelompok penindas dan yang tertindas tidak tumbuh subur dalam kampus dan dunia ini. 


\section{Konsientisasi dan Tantangannya}

Konsientisasi merupakan kondisi di mana manusia memperoleh dirinya yang manusiawi dengan penuh kesadaran melihat dan melakukan sesuatu. Sistem pendidikan yang bercorak penekanan konsientisasi merupakan hal yang tidak terbilang mudah untuk diterapkan dalam tubuh pendidikan kita khususnya di kampus karena mengingat bahwa pasca bergabungnya Indonesia di salah satu organisasi internasional yang bisa dikategorikan berhaluan kapitalisme. Hal demikian pula ditekankan oleh Siti Murtiningsih dalam tesisnya yang sekarang dikemas ke dalam bentuk buku.

Kebijakan politik dan ekonomi mengedepankan strategi pertumbuhan ekonomi dengan program industrialisasi yang masif. Karena itu, secara perlahan tapi pasti, bangsa kita telah masuk dalam sistem kapitalisme industri sebagai tulang punggung pertumbuhan ekonomi dan pembangunan negara.... lebihlebih, kalau keputusan politik dikenakan pada strategi pendidikan nasional, maka bisa dipastikan sistem tersebut akan dipenuhi tendensi kebijakan yang mengabdi pada kepentingan kapitalisme industri. Situasi ini menjadi semakin kompleks manakala Indonesia menjadi anggota sebuah lembaga kapitalisme internasional, yang berarti kucuran modal asing memperoleh tempat cukup kuat dalam perekonomian kita. (Hal. 117-118)

Orientasi pertumbuhan ekonomi akan mempengaruhi setiap kebijakan yang dikeluarkan dan tentunya mendukung orientasi tersebut sehingga hal demikian pula menjalar ke dalam sistem pendidikan. Orientasi pendidikan sesuai dengan tuntutan kapitalisme industri makanya tak asing jika kebanyakan melanjutkan dan menganggap pendidikan sebagai sebuah alat untuk meretas kemiskinan perorangan dan menjadikan pendidikan sebagai kendaraan untuk memasuki dunia pekerjaan yang tentunya menuju pada dunia industri sehingga wajah asli pendidikan bukan lagi sarana penumbuhan dan pengasahan kesadaran manusia melainkan ruang imaji kekayaan di masa depan.

Selain daripada itu, pendidikan sebagai perpanjangan tangan dunia industri sehingga mekanisme pengelolaan pendidikan memiliki kecenderungan praktis dan tidak membebaskan manusia ditambah lagi roh-roh feodalisme masih bersemayam sebagai efek dari penjajahan maka tak heran pula jika hubungan antara pendidik dan peserta didik menjadi paternalistik yakni anggapan bahwa pendidik adalah seorang 'bos' yang harus dipatuhi dan diikuti oleh para peserta didik selaku karyawan ataupun bawahan.

Namun tidak terlepas daripada itu, hal yang mampu mencerahkan semuanya termasuk kebijakan pendidikan yakni amanah daripada konstitusi negeri ini yang seharusnya dikembalikan kepada hakikat dan urgensinya sehingga akan terjadi semacam rekonstruksi tatanan pendidikan yang mengarah kepada pembebasan, penyadaran dan para pendidikpeserta didik tampil selaras dalam pergulatan ilmu pengetahuan. Konstitusi di negeri ini harus didirikan dan ditegakkan dengan prinsip keadilan dan kemanusiaan bukan hanya dijadikan sebagai bentuk amanah yang kaku dalam artian bahwa menjadikan konstitusi hanya sekedar bangunan citra populis namun pada dunia nyata pada proses penerapannya menjadi antipopulis.

Oleh karena itu, segala polemik dalam dunia pendidikan termasuk ruang pembelajaran yang menawarkan sesuatu yang tidak diinginkan oleh para peserta didik karena kecenderungan 
menganggap peserta didik sebagai objek bukan pelaku dalam melihat realitas sosial mampu teratasi dengan mengembalikan tatanan nyata konstitusi dengan menyesuaikan apa yang tertulis dengan apa yang terjadi sehingga wajah asli pendidikan sebagai bentuk pembebasan dari tatanan yang menindas mampu diterapkan dengan bijak. Pendidikan yang menekankan konsientisasi akan mewujudkan tujuan pendidikan nasional sebagai ruang penyadaran manusia untuk memanusiakan manusia.

\section{Daftar Pustaka}

Murtiningsih, Siti. 2004: Pendidikan Alat Perlawanan, Teori Pendidikan Radikal Paulo Freire, Resist Book

Freire, Paulo, (1970) Cultural Action for Freedom, Massachusetts: Harvard Educational Review and Centre for Study of Development and Social Change (1972) Pedagogy of the Oppressed, Sheed and Ward Ltd. 33 London: Maiden

Lane (1979) Education for Critical Consciousness, London: Sheed and Ward

Sutrisno, M. 1995: Pendidikan Pemerdekaan, Jakarta: Yayasan Obor

Bourdieu, Pierre. 2009: (Habitus $x$ Modal $)+$ Ranah = Praktik. Yogyakarta: Jalasutra

Martono, Nanang. 2012: Kekerasan Simbolik di Sekolah; Sebuah Ide Sosiologi Pendidikan Pierre Bourdieu. Jakarta: PT. Raja Grafindo Persada 